\title{
THE RIGHT TO HEALTHCARE IN THE EUROPEAN UNION AND CANADA: THE ROLE OF THE CENTRE IN COMPLEX ENTITIES
}

\author{
Tomislav Sokol *
}

\begin{abstract}
The right to healthcare is a socio-economic right. It is positive in the sense that governments need to provide resources and set the priorities for individuals to be able to exercise it. The provision of healthcare within complex political entities such as the European Union (EU) and Canada is divided between different actors, namely the federal government and provinces in the case of Canada, and European institutions and Member States in the case of the EU. The paper analyses the EU and Canadian legal frameworks and attempts to determine the right balance of power between the centre and the constituent parts in order to facilitate the exercise of the right to healthcare.
\end{abstract}

Keywords: Canada, complex entities, division of powers, proportionality, right to healthcare

\section{Introduction}

The right to healthcare has several different aspects, or meanings. It can mean access to healthcare facilities, which can be limited by physical obstacles, geographic distances, etc. On the other hand, it can also mean access to healthcare services in accordance with uniform, objective criteria based on clinical need rather than ability to pay. The right to healthcare in the latter sense is the focus of this paper. ${ }^{1}$

The rights of citizens can be divided into three types: civil, political and social. Civil rights are those which are necessary for the exercise of individual freedom, such as the right to private property, freedom of thought and speech, liberty of the person, and the like. These rights are negative in the sense that they generally require the state to refrain from intervening, and are forcefully protected by the justice system. Political rights include the right to participate in the exercise of political power, either to be elected in a body vested with that power, or to elect members of such a body. Finally, social rights entail the right to economic welfare

\footnotetext{
" Senior Lecturer at Zagreb School of Economics and Management; Assistant Professor at the Catholic University of Croatia; Member of the European Parliament, orcid.org/00000002-3592-2967. DOI: 10.3935/cyelp.15.2019.333.

1 This principle can be seen, for example, in Council, 'Council Conclusions on Common values and principles in European Union Health Systems' (2006).
} 
and to live a life in accordance with standards which are dominant in a given society. ${ }^{2}$

The right to healthcare belongs to the last-mentioned type, and can be described as a socio-economic right. It is positive in the sense that the government has to provide resources and determine priorities for individuals to be able to take advantage of it. On the other hand, limited resources mean that prioritisation of certain treatments and/or categories of persons may leave individual patients without access to the healthcare they consider necessary for their own wellbeing. Hence, tensions between an individual's right to a particular healthcare treatment, and the priorities of the system to provide resources in areas where they would achieve the best results (according to criteria such as cost-effectiveness), may develop. Possibilities for the justice system to intervene in these cases are limited, since such interventions would require the courts to engage in setting policy priorities which they are ill equipped to do. The situation becomes even more complicated in the case of complex political entities such as the European Union and Canada, where the provision of healthcare is divided between different actors. These actors are the federal government and provinces in the case of Canada, and European institutions and Member States in the case of the EU. ${ }^{3}$ Canada and the EU are complex in the sense that the centre (the Canadian federal government and the Union institutions) and the constituent parts (Canadian provinces and the EU Member States) conduct their policies in different areas through an interwoven relationship where their powers are strongly intertwined and mutually connected. In the described circumstances, the division of power between the said actors crucially affects the individual's ability to access healthcare.

The aim of the paper is to analyse the EU and Canadian legal framework and determine whether the role of the 'centre' (namely, the European Union institutions and the federal government) facilitates or makes the exercise of the individual right to healthcare more difficult. The Canadian system has been chosen as a comparator for several reasons, which will be further explored in the following sections. First, in both

\footnotetext{
2 See T Marshall, Citizenship and Social Class and Other Essays (CUP 1950) 10-11. On the issue of citizenship, see also, for example, P Breiner, 'Is Social Citizenship Really Outdated? T. H. Marshall Revisited' (Meeting of the Western Political Science Association, Albuquerque, March 2006); S Greer (ed), Devolution and Social Citizenship in the United Kingdom (Bristol Policy Press 2009); S Greer and T Sokol, 'Rules for Rights: European Law, Health Care and Social Citizenship' (2014) 20 European Law Journal 66; C Newdick, 'Citizenship, Free Movement and Health Care: Cementing Individual Rights by Corroding Social Solidarity' (2006) 43 CML Rev 1645; A Rees, 'TH Marshall and the Progress of Citizenship' in M Bulmer and A Rees (eds), Citizenship Today: The Contemporary Relevance of TH Marshall (Routledge 2016).

3 See on the general overview of EU health law and policy, for example, T Hervey, C Young and L Bishop (eds), Research Handbook on EU Health Law and Policy (Edward Elgar 2017).
} 
systems, healthcare remains a primary competence of the constituent parts, with an increasingly important role played by the centre in recent years. Second, courts have significantly contributed to the latest trends. Third, there exist different approaches of the two systems in the way these powers are divided, a fact which can offer a new perspective concerning the EU constitutional setup.

The paper first analyses elements of the EU legal framework dealing with healthcare and the division of power between the EU and the Member States in this regard. It then analyses the Canadian legal framework, focusing on the division of power regarding healthcare provision between the federal government and the provinces. The paper then compares the cases of EU and Canada and tries to determine the right balance of power between the centre and the constituent parts in order to facilitate the exercise of the right to healthcare.

\section{The EU constitutional framework}

The primary sources of European Union law are the Treaty on European Union (TEU), the Treaty on the Functioning of the European Union (TFEU), the Charter on Fundamental Rights of the European Union (EU Charter) and the general principles of EU law. According to Article 6 TEU, the EU recognises the rights, freedoms and principles prescribed by the Charter of Fundamental Rights of the European Union of 7 December 2000, as adapted at Strasbourg, on 12 December 2007, which have the same legal value as the Treaties. Charter provisions do not extend the powers of the Union as prescribed by the Treaties. Furthermore, fundamental rights, as protected by the European Convention for the Protection of Human Rights and Fundamental Freedoms, and as they derive from the constitutional traditions which are common to the Member States, constitute general principles of EU law.

According to Article 5 TEU, Union powers (competences) are limited by the principle of conferral. This principle means that the EU may act only within those powers which have been conferred upon the Union by its Member States via the TEU and TFEU to achieve the objectives of the Treaties. The use of Union competences is subject to the principles of subsidiarity and proportionality. Subsidiarity means that the EU, in the areas which are not within the exclusive powers of the Union, may act only when the objective of the said action cannot be sufficiently achieved by the EU Member States, but can be better achieved at the EU level. The principle of proportionality means that EU actions will not go beyond what is necessary to achieve the Treaty objectives. ${ }^{4}$

\footnotetext{
${ }_{4}$ On the general principles of EU law, see, for example, K Lenaerts and J Gutiérrez-Fons, 'The Constitutional Allocation of Powers and General Principles of EU Law' (2010) 47 CML
} 
The European Union has several different types of powers. First, there are the exclusive powers. According to Article 2 TFEU, when the Treaties give the EU exclusive power (competence) in a given area, only the EU may adopt legally binding acts in this area. The Member States may act only if they are specifically granted that power by the EU, or they may act to implement the acts of the EU. Exclusive powers of the Union are enumerated in Article 3 TFEU and cover six areas, mainly concerning trade and monetary policy. Concurrent (shared between the EU and the Member States) powers mean that the Member States may adopt legally binding acts if the EU has not done so in a certain area. The Member States are allowed to exercise their power when the Union decides to cease exercising its power in the said area. Concurrency covers most areas of Union action, ranging from the internal market free trade provisions, to social policy and public health, as stipulated by Article 4 TFEU. Next, according to Article 2 TFEU, the EU has powers to coordinate the economic and employment policies of the EU. Finally, the EU has the power to coordinate, support or supplement the policies of the Member States in certain fields, without harmonising national legislation. The latter areas include the protection and improvement of human health, pursuant to Article 6 TFEU.

A crucial area of European Union action is the internal market, which falls within the area of concurrent powers. The power to regulate the said field, through the approximation of national laws, is interpreted rather broadly, arising whenever there is an issue existing in several EU Member States. An example of such an approach can be seen in the jurisprudence of the Court of Justice of the EU, concerning the prohibition of tobacco advertising. ${ }^{5}$ According to the Court, the mere finding of certain differences between Member States' rules is not enough to justify EU legislative action. However, the Union may act when there are disparities between the Member States' laws, regulations or administrative provisions which obstruct the freedoms of movement (of goods, persons, services, establishment and capital) across national borders and thus directly affect the functioning of the EU internal market. Furthermore, EU legislative action is possible if its objective is to prevent the emergence of some future obstacles to trade due to different developments of Member States' laws. The emergence of the said obstacles must be likely and the EU legislative measure must be designed to prevent it. Additionally:

Rev 1629. See also A Estella de Noriega, The EU Principle of Subsidiarity and Its Critique (OUP 2002) and T Harbo, 'The Function of the Proportionality Principle in EU Law' (2010) 16 European Law Journal 158.

5 See Case C-380/03 Federal Republic of Germany $v$ European Parliament and Council of the European Union ECLI:EU:C:2006:772. 
It follows from the foregoing that when there are obstacles to trade, or it is likely that such obstacles will emerge in the future, because the Member States have taken, or are about to take, divergent measures with respect to a product or a class of products, which bring about different levels of protection and thereby prevent the product or products concerned from moving freely within the Community, Article 95 EC authorises the Community legislature to intervene by adopting appropriate measures, in compliance with Article 95(3) EC and with the legal principles mentioned in the EC Treaty or identified in the case-law, in particular the principle of proportionality. ${ }^{6}$

Although the Court of Justice stated that the mere finding of disparities between Member States is not enough for the Union to act, but that real or potential obstacles to trade must exist, the existence of the said obstacles has been interpreted very broadly by the Court. Besides:

Recourse to Article $95 \mathrm{EC}$ as a legal basis does not presuppose the existence of an actual link with free movement between the Member States in every situation covered by the measure founded on that basis. As the Court has previously pointed out, to justify recourse to Article $95 \mathrm{EC}$ as the legal basis what matters is that the measure adopted on that basis must actually be intended to improve the conditions for the establishment and functioning of the internal market. ${ }^{7}$

In the particular case, EU legislation regulated media with no connection to the EU cross-border market. The existence of obstacles to trade was also not based on any concrete evidence, but was primarily deduced from the fact that certain Member States regulate advertising of tobacco more restrictively than others (and the EU even strengthened those limitations). It has also been stated in the literature that 'the consequent dynamic in favour of an EU regulatory competence that is in principle limited but in practice truly broad is evident'. ${ }^{8}$ In this sense, it is possible to say that the tendency of shifting the balance of regulatory power from the national to the EU level can be observed.

Of course, the case law is still evolving. A recent example is Czech Republic $v$ European Parliament and Council concerning Directive 2017/853 adopted on the basis of Article 114 TFEU which limits the trade of firearms. Here, Advocate General Sharpston in her recent opinion stated that the test is whether, taking into account its content and taken as a whole,

6 ibid, para 41. Article $95 \mathrm{EC}$ is the current Article 114 TFEU.

7 ibid, para 80.

8 See S Weatherill, 'The Limits of Legislative Harmonization Ten Years after Tobacco Advertising: How the Court's Case Law has become a "Drafting Guide"' (2011) 12 German Law Journal 839. See also, for example, Case C-491/01 The Queen $v$ Secretary of State for Health, ex parte British American Tobacco (Investments) Ltd ECLI:EU:C:2002:741. 
the directive in question eliminates obstacles to free movement and/or prevents the emergence of future obstacles. The Advocate General in the concrete case found the Czech Republic's plea that the directive aims at regulating public safety and security and not to eliminate obstacles to the internal market unfounded. The argument was that the directive's primary purpose was to eliminate obstacles to free trade by introducing harmonised rules to ensure that Member States do not need to take individual (possibly disparate) action. In her opinion, the directive promotes the objectives of the internal market whilst taking into account the need to enhance provision for public safety. However, the actual limitations to the free movement of goods that the directive purportedly removes are presumed by the Advocate General and are not concretely proven. This approach seems to be in line with the case law shifting the balance of power towards the EU, but one has to wait for the actual judgment to see whether the Court will follow suit. ${ }^{9}$

\section{EU healthcare system(s)}

The first thing to notice about the European Union healthcare system is that it is not a single system at all. As prescribed by Article 168 TFEU, the EU respects:

the responsibilities of the Member States for the definition of their health policy and for the organisation and delivery of health services and medical care. The responsibilities of the Member States shall include the management of health services and medical care and the allocation of the resources assigned to them.

Union action must be focused on complementing the national actions and policies in different areas, such as public health protection, epidemics, etc. It is also prescribed that the EU will encourage cooperation between Member States, especially concerning the complementarity of healthcare services in border areas. Incentive measures which the EU may enact in order to protect and improve human health may not include harmonisation of the laws and regulations of the Union Member States.

One exception concerns medicines regulation. Here, according to Article 168 TFEU, the EU may enact the following: rules setting high standards of quality and safety of organs and substances of human origin, blood and blood derivatives; rules in the veterinary and phytosanitary fields which have as their direct objective the protection of public health; and rules setting high standards of quality and safety for medicinal products and devices for medical use. In practice, the EU regulates

\footnotetext{
9 See Case C-482/17 Czech Republic $v$ European Parliament Council of the European Union, Opinion of AG Sharpston, paras 39-76.
} 
the placing of medicines on the EU market. This includes manufacturing, wholesaling, advertising, clinical trials, supervision, etc. The European Medicines Agency is tasked with evaluating medicines according to safety standards, while the final marketing approval is given by the European Commission. Medicines must also be approved by the Member States in order to be covered by their health insurance systems, whose spending covers the majority of cost of medicines in the European Union. ${ }^{10}$

As noted when mentioning Article 168 TFEU, the Member States are responsible for organising and delivering (including financing) healthcare to the population, which they conduct through their (social security) health insurance systems. The health insurance systems of the EU are recognised as a central part of Europe's high levels of social protection, contributing to social cohesion and social justice as well as to its sustainable development. They are based on the health values of universality, solidarity, access to good quality care and equity. Universality means that access to healthcare is not prohibited to anyone; solidarity is connected with the financial arrangement of Member States' health systems and the need to ensure accessibility of healthcare provision to all; equity means equal access based on need, regardless of ethnicity, age, gender, ability to pay or social status. ${ }^{11}$ Healthcare resources of the Member States' systems are in this sense crucial for the delivery of healthcare in the EU. The possibilities of the EU to harmonise these national health insurance systems is practically non-existent. One such possibility is prescribed by Article $153 \mathrm{TFEU}$, which provides that the EU may adopt, in several areas including social security (via directives), the minimum

\footnotetext{
10 See, on these issues, European Parliament and Council Regulation (EC) 726/2004 of 31 March 2004 laying down Community procedures for the authorisation and supervision of medicinal products for human and veterinary use and establishing a European Medicines Agency [2004] OJ L136/1. See also European Parliament and Council Directive 2001/83/ EC of 6 November 2001 on the Community code relating to medicinal products for human use [2001] OJ L311/67 and European Parliament and Council Regulation (EU) 536/2014 of 16 April 2014 on clinical trials on medicinal products for human use and repealing Directive 2001/20/EC [2014] OJ L158/1. On the national approval process for the coverage of medicines, see Council Directive 89/105/EEC relating to the transparency of measures regulating the prices of medicinal products for human use and their inclusion in the scope of national health insurance systems [1989] OJ L40/8. See also J Borg et al, 'Strengthening and Rationalizing Pharmacovigilance in the EU: Where is Europe Heading to?' (2011) 34 Drug Safety 187; G Permanand, E Mossialos and M McKee, 'Regulating Medicines in Europe: The European Medicines Agency, Marketing Authorisation, Transparency and Pharmacovigilance' (2006) 6 Clinical Medicine 87; J Regnstrom et al, 'Factors Associated with Success of Market Authorisation Applications for Pharmaceutical Drugs Submitted to the European Medicines Agency' (2010) 66 European Journal of Clinical Pharmacology 39; S Vogler et al, 'Pharmaceutical Policies in European Countries in Response to the Global Financial Crisis' (2011) 4 Southern Med Review 69.
}

11 Council (n 1). 
requirements for gradual implementation, limited to supporting and complementing the national activities. However, the said measures in the area of social security may only be enacted through a consensus of the Member States in the Council, meaning there is not much chance of adopting them (and none of them have been adopted yet).

As can be observed, explicit legal bases concerning healthcare and social security in the Treaties are rather limited in scope. On the other hand, EU legal rules which influence national health insurance systems are based on the provision of the TFEU on facilitating free movement. One of these legal bases is Article 21 TFEU which makes it possible to adopt measures concerning social security or social protection for economically non-active persons to facilitate the free movement of EU citizens across national borders. Another legal basis is Article 48 TFEU which aims at facilitating the free movement of workers between Member States. The latter provision has traditionally been the legal basis for adopting rules on the coordination of national social security systems. These EU rules aim at protecting social security rights (including healthcare) for migrant workers who come into contact with different national systems due to working and/or living in several Member States. The crucial principles of the coordination system concerning access to healthcare are equal treatment (prohibition of discrimination of other Member States' nationals) and the designation of one applicable legislation that migrants are subjected to. These rules, inter alia, contain the right to obtain authorisation from the state of insurance for (social) health insurance coverage of elective healthcare in another Member State. The authorisation is given if the treatment in question is provided by the legislation of the Member State of (social) health insurance and if the insured person cannot be given such treatment in the state of insurance within a time limit which is medically justifiable, considering the person's state of health and the probable course of illness. ${ }^{12}$ Here, one can see that the EU essentially imposes certain market-oriented regulatory requirements on national health insurance systems, while the maintenance and financing of these social insurance systems is left to the Member States.

\footnotetext{
12 See Regulation (EC) 883/2004 of the European Parliament and of the Council of 29 April 2004 on the coordination of social security systems [2004] OJ L166/1. Another historically important legal basis is the current Art 352 TFEU which provides that, if action by the EU is necessary, within the framework of the policies defined in the Treaties, to attain one of the Treaty objectives, and the Treaties have not provided the necessary powers, the Council, acting unanimously on a proposal from the European Commission and after gaining the consent of the European Parliament, will adopt the appropriate measures.
} 


\section{Free movement of services}

The previous sections have focused on the division of powers between the European Union and the Member States generally and specifically in the field of healthcare. However, the crucial legal basis which has, in practice, had an important influence on the individual's access to healthcare in the EU concerns the free movement of services. According to the current Article $56 \mathrm{TFEU}$, all restrictions on freedom to provide services within the EU are prohibited concerning nationals of Member States who are established in a Member State other than the state of the person for whom the services are intended. Crucial case law on the said provision concerns the right to obtain healthcare outside one's Member State of social health insurance under the coverage of that health insurance. This case law has developed the right to socially covered elective cross-border healthcare in parallel to the existing system of social security coordination. The said jurisprudence has, in the meantime, been codified through another piece of EU secondary legislation, the Patients' Rights Directive, with harmonisation of the internal market as the primary legal basis for adoption. ${ }^{13}$

The first notable decision, Kohll, in which the Court of Justice of the EU tackled the right to access cross-border healthcare was rendered in 1998. The dispute was between a Luxembourg national (Mr Kohll) and his Luxembourg social health insurance concerning a request by a doctor established in Luxembourg for authorisation for his daughter, who was a minor, to receive orthodontist treatment in Germany. The refusal of authorisation was challenged before Luxembourg courts, and the Court of Cassation referred the case to the Court of Justice for a preliminary ruling. ${ }^{14}$

The Court concluded that the freedom to provide services is applicable to the cases of persons who seek to obtain (social) health insurance coverage of medical treatment in another EU Member State. Next, it turned to the question of whether imposing mandatory prior authori-

\footnotetext{
13 See Directive 2011/24/EU of the European Parliament and of the Council on the application of patients' rights in cross-border healthcare [2011] OJ L88/45 (Patients' Rights Directive). The Directive and the case law have been extensively analysed in the literature. See, for example, S de La Rosa, 'The Directive on Cross-border Healthcare or the Art of Codifying Complex Case Law' (2012) 49 CML Rev 15; M Peeters, 'Free Movement of Patients: Directive 2011/24 on the Application of Patients' Rights in Cross-Border Healthcare' (2012) 19 European Journal of Health Law 29; K Raptopoulou, 'The Directive on Cross-border Health Care: Signalling the Coordination or the Harmonisation of Public Health Systems?' (2012) European Journal of Social Law 193; G Strban, 'Patient Mobility in the European Union: Between Social Security Coordination and Free Movement of Services' (2013) 14 ERA Forum 391; J van de Gronden et al (eds), Health Care and EU Law (TMC Asser Press 2011).

14 See Case C-158/96 Raymond Kohll v Union des caisses de maladie ECLI:EU:C:1998:171.
} 
sation, as a requirement for obtaining the said coverage, is a restriction of the free movement of cross-border services. Here, the Court stated that, although the described national rules do not deprive insured persons of the possibility of approaching a provider of healthcare services established in another EU Member State, they do nevertheless make reimbursement of the costs of those services subject to prior authorisation, and deny reimbursement to persons who have not obtained the authorisation. On the other hand, costs incurred in the Member State of insurance are not subject to that authorisation. Therefore, the rules in question deter insured persons from accessing healthcare providers established in another Member State and constitute, for the providers and their patients, a barrier to the freedom to provide (and receive) services. ${ }^{15}$

Then the Court analysed the possibilities to justify such a restriction to free movement on the basis of public interest, as provided by the current Article 52 TFEU and the case law. In order to be justified, the national measures in question must be suitable for achieving the stated objective. Next, they must be necessary to achieve the said objective and must represent the least possible restriction on free movement. Finally, proportionality stricto sensu between the measure's effects and its objective must exist. ${ }^{16}$ In Kohll, the Court concluded that the freedom to receive health treatment in another Member State does not endanger public health, whose protection was stated as justification for the measure in question by Luxembourg. The reasoning was that the conditions for taking up and pursuing the profession of doctor and dentist have been regulated by several coordinating or harmonising directives of the EU. Therefore, doctors and dentists established in other Member States must be given the same guarantees as doctors and dentists established on the national territory of the state of insurance, for the purposes of the free provision of services. Additionally, Luxembourg tried to justify its prior authorisation requirement by the necessity to provide a balanced and accessible healthcare service. The Court did not accept this justification, since there was no proof that the rules in question were indispensable for the maintenance of an essential health treatment facility or service on national territory. Imposing prior authorisation for such treatments was, thus, considered contrary to the TFEU provisions on the free movement of services. ${ }^{17}$

Subsequent case law has refined and further explained the approach of the Court of Justice to the right to cross-border healthcare. It has also expanded that right to healthcare systems which are free-of-

\footnotetext{
15 Kohll (n 14) paras 31-35.

16 Harbo (n 4) 165.

17 Kohll (n 14) paras 37-53.
} 
charge at the point of delivery, unlike the system in Luxembourg based on the reimbursement of expenses. ${ }^{18}$ One well-known decision in this regard is Watts, related to the UK's National Health Service. The case was about Mrs Watts, residing in the UK (and covered by its health system) who was refused authorisation to obtain a hip replacement abroad. According to the applicable rules on coordination of social security systems, authorisation for the coverage of treatment abroad could only be given when the treatment in question was covered by the legislation of the state of health insurance and such treatment could not be provided in that state within the time normally necessary for obtaining the treatment in question (without undue delay). The national authorities considered that Mrs Watts could receive treatment in a local hospital within the government's NHS Plan targets and therefore 'without undue delay'. In practice, this meant she would have to wait about a year for her hip replacement. Mrs Watts then obtained the treatment in France and asked for reimbursement from the UK and the case finally went to the Court of Justice of the EU. ${ }^{19}$

On the issue of undue delay and waiting lists, the Court concluded the following:

It follows that, where the delay arising from such waiting lists appears to exceed in the individual case concerned an acceptable period having regard to an objective medical assessment of all the circumstances of the situation and the clinical needs of the person concerned, the competent institution may not refuse the authorisation sought on the grounds of the existence of those waiting lists, an alleged distortion of the normal order of priorities linked to the relative urgency of the cases to be treated, the fact that the hospital treatment provided under the national system in question is free-of-charge, the duty to make available specific funds to reimburse the cost of treatment provided in another Member State and/or a comparison between the cost of that treatment and that of equivalent treatment in the competent Member State. $^{20}$

It can be seen from the quoted paragraph that the individual's right to healthcare has priority over the general need for planning and prioritising healthcare resources when deciding on the issue of prior authori-

\footnotetext{
18 The first judgment on a system not based on reimbursement was Case C-157/99 BSM Geraets-Smits $v$ Stichting Ziekenfonds VGZ ECLI:EU:C:2001:404. One important element is that the case law has recognised that the prior authorisation requirement can be justified for hospital treatments and treatment involving major medical equipment. See, for example, Case C-512/08 European Commission v French Republic ECLI:EU:C:2010:579, paras 26-44.

19 See Case C-372/04 The Queen, on the application of Yvonne Watts $v$ Bedford Primary Care Trust ECLI:EU:C:2006:325.
}

20 Watts (n 19) para 120. 
sation. The Court here does not even consider a less restrictive alternative which is the usual form of the proportionality test it uses. In the case of literally applying such a test, the question would be if the national resource planning concerns can be achieved by an authorisation system and waiting lists which are less cumbersome for patients. If this is impossible, the Member State in question should be allowed to retain its system, although an individual patient might wait longer than is 'acceptable having regard to an objective medical assessment', whatever that means. The Court, however, has not utilised the usual proportionality test, thereby giving strong preference to individual needs when determining whether to grant authorisation or not.

Apart from waiting lists as a means of healthcare planning, another issue which has been tackled by the Court of Justice concerns the right of a Member State of insurance to define the basket of health services it covers. The crucial decision in this respect was rendered in Geraets-Smits, the first to deal with a benefits-in-kind healthcare system. In this case, a person insured in the Netherlands suffering from Parkinson's disease underwent treatment in Germany and asked for reimbursement from the Dutch health insurance. Reimbursement was refused, partly on the basis that the clinical method in question was not regarded as normal treatment within the relevant professional circles and was therefore not covered by the Dutch health insurance legislation. The case also went to the Court of Justice, which concluded that the Netherlands' legislation did not contain a detailed list of healthcare treatments covered by domestic health insurance, but referred to treatments "normal in the professional circles concerned' instead. According to the Court, 'only an interpretation on the basis of what is sufficiently tried and tested by international medical science can be regarded as satisfying'. In other words, Member States which broadly define what they cover by referring to standards recognised by the medical profession have to cover foreign treatments which are not recognised by the medical profession in their own territory. ${ }^{21}$

Of course, it is hard to speak of some universal standard of the medical profession, since such standards are not harmonised at the EU level, let alone at the global level. There can be multiple reasons why a certain treatment is considered standard in one country and not in another, ranging from the technological (lack of relevant clinical testing) to the ethical (in vitro fertilisation or abortion, for instance). The approach of the Court of Justice stimulates countries to limit the cover by prescribing in detail the content of their health insurance baskets. This approach would reduce the flexibility of the system and make it harder to keep up

21 See Geraets-Smits (n 18). 
with rapid changes in medical technology. It can be seen that the Court of Justice has limited the Member States' possibilities of making funding and rationing decisions in accordance with domestic resources and priorities.

This approach has generally been taken over by the Patients' Rights Directive. For example, it is stated in its preamble that, if the national legislation does not specify precisely the treatment method applied but defines types of treatment more broadly, a Member State should not refuse prior authorisation or reimbursement on the grounds that the treatment method is not available in its territory, but should assess whether the treatment in question corresponds to the benefits provided for in its legislation. ${ }^{22}$ Thereby, the Directive provides an incentive for Member States to define their coverage in a more detailed and rigid legislative manner in order to be able to remain competent for defining their systems' priorities. It should be mentioned that the Court has limited certain aspects of cross-border healthcare in the more recent case law, an approach taken over and expanded by the Directive. This has been the case, for instance, by allowing the prior authorisation requirement to be justified for hospital treatments and treatment involving major medical equipment, ${ }^{23}$ thereby 'protecting the organisational structures and capacities of national health systems, and their financial viability', as stated by Hervey. ${ }^{24}$ On the other hand, the question of defining coverage still remains contentious, as shown above.

\section{Coordination of fiscal and economic policies}

Another important aspect of the EU legal framework influencing the right to healthcare concerns coordination of the fiscal and macroeconomic policies of the Member States, including caps on their public expenditure. The key instrument which sets these limitations is the Stability and Growth Pact which aims to maintain the stability of the EU Economic and Monetary Union. The Pact has set thresholds of $60 \%$ of GDP relating to public debt and 3\% of GDP relating to annual government deficit. If the said thresholds are breached, the Council may initiate a special Excessive Deficit Procedure which may result in financial penalties for the concerned Member State. ${ }^{25}$

\footnotetext{
22 See Preamble to the Patients' Rights Directive (n 13) para 34.

23 See Commission v France (n 18) paras 94-98 and the Patients' Rights Directive (n 13) Art 8.

24 See T Hervey, Telling Stories about European Union Health Law: The Emergence of a New Field of Law' (2017) 15 Comparative European Politics 352.

25 See Art 126 TFEU and Protocol 12 on the excessive deficit procedure. See also Council Regulation (EC) 1466/97 of 7 July 1997 on the strengthening of the surveillance of budget-
} 
The economic crisis which started in 2008 has put pressure on European Union Member States to give strong powers to the institutions of the EU, especially those dealing with fiscal issues, regarding the control of national economic and fiscal policies, including healthcare spending. The strongest mechanism of control, involving the European Central Bank, the European Commission and the International Monetary Fund (the Troika) has focused on those countries which belong to the Economic and Monetary Union (Eurozone). The Eurozone countries, which need financial assistance from the International Monetary Fund and the European Union, must fulfil certain conditions. The said conditions include reforms in social and economic policies set by Memorandums of Understanding (MoUs) concluded between the Member States and those institutions. These Memorandums are based on the intergovernmental European Stability Mechanism established by the countries of the Eurozone and are not part of internal EU law. This mechanism has generally taken over the tasks previously fulfilled by the European Financial Stabilisation Mechanism and the European Financial Stability Facility (which are still in existence) and represents a strong instrument for ensuring countries' compliance. The European Commission primarily monitors whether the countries fulfil the conditions which are set by the MoUs. Non-compliance of the countries concerned may result in penalties and stricter conditions for future assistance. ${ }^{26}$

As far as other EU Member States are concerned, crucial instruments are determined through the framework of the European Semester for economic policy coordination. Within the Semester, there is a 'soft' governance framework regarding Member States' social and employment policies. This framework has complemented the strong coordination of national fiscal and macroeconomic policies established by the Stability and Growth Pact. The Semester starts in November of each year when the European Commission determines Union priorities in terms of job

ary positions and the surveillance and coordination of economic policies [1997] OJ L209/1 and Council Regulation (EC) 1467/97 of 7 July 1997 on speeding up and clarifying the implementation of the excessive deficit procedure [1997] OJ L209/6. See also T Sokol and N Mijatović, 'EU Health Law and Policy and the Eurozone Crisis' in T Hervey, C Young and L Bishop (eds), Research Handbook on EU Health Law and Policy (Edward Elgar 2017) 292.

${ }_{26}$ See Art 136 TFEU and Treaty Establishing the European Stability Mechanism between the Kingdom of Belgium, the Federal Republic of Germany, the Republic of Estonia, Ireland, the Hellenic Republic, the Kingdom of Spain, the French Republic, the Italian Republic, the Republic of Cyprus, the Grand Duchy of Luxembourg, Malta, the Kingdom of the Netherlands, the Republic of Austria, the Portuguese Republic, the Republic of Slovenia, the Slovak Republic and the Republic of Finland. See also Art 122 TFEU, European Financial Stability Facility Consolidated Articles of Association and Council Regulation (EU) 407/2010 of 11 May 2010 establishing a European financial stabilisation mechanism [2010] OJ L118/1. Under the said rules, the European Financial Stabilisation Mechanism may provide assistance to all EU Member States. 
creation and growth for the following year. On the basis of the Guidelines which are made by the Council, EU Member States prepare National Reform Programmes for the year to come. These programmes are reviewed by the European Commission which makes Country Reports for each of the Member States, analysing their social and economic policies. These are followed by the Council's Country-Specific Recommendations (CSR). Strict procedures for the prevention, detection and correction of macroeconomic imbalances have also been established by Union legislation to ensure national implementation. Thus, monitoring of EU Member States' economic and fiscal policies has been strengthened. The countries need to respect concrete deadlines for correcting their deficits in a sustainable manner. Non-complying Member States may be given policy warnings which are endorsed by the Council and can result in financial penalties. ${ }^{27}$

In what way have the EU instruments of economic policy and fiscal coordination influenced national healthcare systems and the right to healthcare in the Member States? It can be observed that in countries where the EU and the other mentioned institutions had a bigger role to play (Portugal, Ireland and Greece), through Memorandums of Understanding, privatisation and cost-containment became priorities. In Ireland, for example, several co-payments have been newly introduced or increased, including those for prescribed medicines. In Greece, an EUR 25 admission fee and an additional EUR 1 payment (on top of the existing 25\% co-payment) for prescriptions were introduced in 2014. In addition, the number of beds provided through the public system has been slashed by more than 10\%, and for-profit financing of hospitals has been expanded. In countries where the role of the EU has been moderate, healthcare reforms have focused on a 'changing healthcare mix'. There was a shift of control powers from insurance funds either towards the

27 See Council Regulation (EC) 479/2009 of 25 May 2009 on the application of the Protocol on the excessive deficit procedure annexed to the Treaty establishing the European Community (Codified version) [2009] OJ L145/1; Council Directive 2011/85/EU of 8 November 2011 on requirements for budgetary frameworks of the Member States [2011] OJ L306/41; European Parliament and Council Regulation (EU) 1173/2011 of 16 November 2011 on the effective enforcement of budgetary surveillance in the euro area [2011] OJ L306/1; European Parliament and Council Regulation (EU) 1174/2011 of 16 November 2011 on enforcement measures to correct excessive macroeconomic imbalances in the euro area [2011] OJ L306/8; European Parliament and Council Regulation (EU) 1176/2011 of 16 November 2011 on the prevention and correction of macroeconomic imbalances [2011] OJ L306/25; European Parliament and Council Regulation (EU) 472/2013 of 21 May 2013 on the strengthening of economic and budgetary surveillance of Member States in the euro area experiencing or threatened with serious difficulties with respect to their financial stability [2013] OJ L140/1; and European Parliament and Council Regulation (EU) 473/2013 of 21 May 2013 on common provisions for monitoring and assessing draft budgetary plans and ensuring the correction of excessive deficit of the Member States in the euro area [2013] OJ L140/11. See also R Baeten and B Vanhercke, 'Inside the Black Box: The EU's Economic Surveillance of National Healthcare Systems' (2017) 15 Comparative European Politics 483. 
market (the Netherlands and Italy), or the State (Germany and France), along with some level of privatisation of healthcare service provision. In the Member States where the EU influence has been weakest, such as the UK, Sweden and Lithuania (some of them are not members of the Eurozone), reforms have focused on systemic reorganisation, based on domestic policy considerations. ${ }^{28}$ Therefore, where the EU influence on national healthcare policies has been strong, the emphasis has been on fiscal consolidation, and not on ensuring individual access to healthcare.

\section{Canadian constitutional framework}

At the outset, the Canadian constitutional framework, in terms of the division of power between the federal level and the provinces, significantly differs from the system set up by the TEU and TFEU. The first difference, of course, is that the Canadian Constitution consists of several codified acts and uncodified traditions and practices. ${ }^{29}$ On the other hand, the Union constitutional framework, as described in the previous sections, is based on international treaties ratified by the Member States, the Charter on Fundamental Rights of the European Union, and the general principles of EU law. Second, most policy areas in the EU remain concurrent, or shared, between the Union and the Member States. In Canada, conversely, concurrency can be seen basically as an exception to the general rule. Section 91 of the Constitution Act 1867 enumerates exclusive competences of the Parliament of Canada in great detail. These powers cover different areas, ranging from issues such as public debt and the regulation of trade and commerce, to unemployment insurance and family law. Section 92 of the Constitution Act 1867 enumerates ex-

\footnotetext{
28 See F Stamati and R Baeten, 'Varieties of Healthcare Reform: Understanding EU Leverage' in D Natali and B Vanhercke (eds), Social Policy in the European Union: State of Play 2015 (European Trade Union Institute 2015) 209-210. On Ireland, see the Health Act 1970, section $59(1 \mathrm{~A}-\mathrm{C})$. Another element which should be mentioned is that the number of persons who have full eligibility for public healthcare increased from $30 \%$ to around $43 \%$ of the Irish population between 2007 and 2013. Additionally, there has been a 70\% increase since 2005. This is important because a person's eligibility depends on a means test, which means that there has been a big increase in the number of persons who are unable to pay for their healthcare without undue hardship. See Health Act 1970, section 45. See also, on this issue, F Paolucci, Health Care Financing and Insurance (Springer 2011) 35; A Nolan and B Nolan, 'Eligibility for Free GP Care, "Need" and GP Visiting in Ireland' (2008) 9 European Journal of Health Economics 157. In Greece, the overall government deficit declined by $3.6 \%$ in 2014 , from double-digit figures in the previous years. See EUROSTAT, 'General Government Deficit (-) and Surplus (+) - Annual Data'.

29 It is stated in the Preamble to the Constitution Act 1867: 'Whereas the Provinces of Canada, Nova Scotia, and New Brunswick have expressed their Desire to be federally united into One Dominion under the Crown of the United Kingdom of Great Britain and Ireland, with a Constitution similar in Principle to that of the United Kingdom.... Since the Constitution of the UK is uncodified, it can be derived that the same underlying principle applies also to Canada.
} 
clusive competences of the provinces, including, for example, 'the establishment, maintenance, and management of hospitals, asylums, charities, and eleemosynary institutions in and for the province, other than marine hospitals'. Section 95 stipulates agriculture and immigration as concurrent between the federal level and the provinces. Rules enacted by the provinces have effect as long as they are not contrary to an Act of Parliament of Canada.

Even though the constitutional division of powers seems pretty straightforward, both the federal government and the provinces have engaged in policy activities not clearly defined by the constitutional provisions. Additionally, the federal level has assumed a more active role in providing social services, such as healthcare and pensions, which have traditionally been assigned to the provinces. ${ }^{30}$ Furthermore, the exclusive power of the federal government to regulate trade and commerce, which might be seen as similar to the TFEU free movement provisions, has raised questions on where the federal power stops and the provincial one begins. In this sense, the Supreme Court of Canada has relatively recently stated that it has evolved into a flexible point of view towards federalism 'that accommodates overlapping jurisdiction and encourages intergovernmental cooperation - an approach that can be described as the 'dominant tide' of modern federalism'. This dominant tide means that the Court rejects an approach of rigidly and formalistically demarking powers of the federal government and provinces, in favour of accommodating cooperative intergovernmental efforts. ${ }^{31}$ Furthermore, the Court has stated that an issue must be 'genuinely national in importance and scope' for it to be within the legislative powers of the federal government concerning trade and commerce. Genuine national importance and scope do not exist solely because the issue at hand exists in all the Canadian provinces, or because some of its aspects have a national dimension. For the federal level to regulate, there must be a problem which provinces cannot solve on their own (either jointly, or individually). ${ }^{32}$

\footnotetext{
30 See, for example, Canada Pension Plan RSC, 1985, c C-8. See also T Hueglin, Treaty Federalism as a Model of Policy Making: Comparing Canada and the European Union' (2013) 56 Canadian Public Administration 193.

31 See Reference re Securities Act [2011] 3 SCR 837, paras 57-58.

32 ibid. This is one of the five criteria for federal legislative intervention set by the Court in General Motors of Canada Ltd $v$ City National Leasing [1989] 1 SCR 641: (1) the legislation in question must be part of a general regulatory scheme; (2) the scheme must be continuously monitored by a regulatory agency; (3) the legislation must be related to trade as a whole and not with a specific industry; (4) the legislation should be such that the provinces jointly or individually would be constitutionally incapable of enacting; and (5) the failure to include one or more provinces or localities would jeopardise the successful operation of the scheme in question in other parts of Canada. This is not a closed list and absence of one of the stated conditions is not crucial for the federal legislative power to exist.
} 
Generally, the Court emphasises concepts like balance and cooperation when determining the limits of federal regulatory power. Despite the concept of 'cooperative federalism' which encourages cooperation between the federal and the provincial level, the constitutional limitations which underlie the division of powers between the federal government and the provinces must still be respected. This 'dominant tide' of constitutional federalism, however strong, 'cannot sweep designated powers out to sea, nor erode the constitutional balance inherent in the Canadian federal state'. Legislation's primary focus on local concerns means it cannot be within the power of the federal level. This is especially the case in areas such as securities, where different provinces have different focuses and specialisations, as evidenced by data (for example, around half of Ontario's securities market is linked to large financial services companies, while Alberta is the dominant national market for oil and gas, etc). ${ }^{33}$

The approach by the Supreme Court seems to be more restrained in terms of broad interpretation of the federal legislative power encroaching upon the provinces' constitutional position when compared to the EU. As observed when analysing the jurisprudence of the Court of Justice, Union competence to regulate the internal market, by way of approximating national laws, is sometimes interpreted as existing whenever there is an issue which exists in several EU Member States. The standard of genuine national scope and importance used by the Supreme Court seems to be stricter and, at least partly, based on some concrete evidence. The latter standard requires that national legislation must be qualitatively different from anything that provinces could achieve without interference by the federal level in order for the federal competence to exist. It should be emphasised that the described interpretation concerns exclusive power of the Canadian Parliament to regulate trade and commerce, while the EU power to regulate the internal market is shared between the Union and the Member States. So, the Supreme Court seems to be more concerned about the constitutional competences of the provinces than the Court of Justice about the competences of the EU Member States.

\section{The Canadian healthcare system}

The Canadian health system is predominantly financed from the public purse. Approximately $70 \%$ of health costs are financed by way of general taxation of the territorial, provincial and federal governments. The system is highly decentralised, which is, inter alia, caused by the provincial and territorial responsibility for the delivery and funding of most health services. ${ }^{34}$ This can be seen in the explicit provision of Section 92

33 Reference re Securities Act (n 31) paras 62, 127.

34 See G Marchildon, Canada: Health System Review (World Health Organisation 2013) 19. 
of the Constitution Act 1867, whereby the maintenance, establishment and management of hospitals falls within the scope of the provinces' legislative competence. The remaining power to regulate healthcare provision is derived from the more general constitutional framework which divides power between the provinces and the federal government. Thus, the residual power to regulate areas not within the explicit competence of the provinces rests with the federal government,

The first area of healthcare where the federal government exercises its authority concerns medicines. Several acts determine prohibitions and penalties, but in practice operate as regulatory statutes aimed at protecting public health. ${ }^{35}$ Among other things, these federal rules (the Food and Drugs Act) set approval processes and standards for the production, testing, packaging and labelling of medicines. Applications for approval to market medicines in Canada are processed by the Health Products and Food Branch. Medicines must also be approved by the provinces in order to be covered by their health insurance. ${ }^{36}$

The second area of healthcare (which is the focus of this paper) in which the federal government plays an important role concerns funding, through the national single-payer healthcare system. ${ }^{37}$ The power to regulate the said issue stems from Section 91 of the Constitution Act 1867 which provides that:

It shall be lawful for the Queen, by and with the Advice and Consent of the Senate and House of Commons, to make Laws for the Peace, Order, and good Government of Canada, in relation to all Matters not coming within the Classes of Subjects by this Act assigned exclusively to the Legislatures of the Provinces.

Additionally, Section 91 gives power to the federal parliament to regulate taxation and public property. The crucial legal source in this respect is the Canada Health Act.

The Canada Health Act, in its sections 7-12, prescribes the requirements for a provincial health insurance system to qualify for federal funding. These consist of five rather simple and straightforward criteria:

\footnotetext{
35 See Food and Drugs Act RSC, 1985, c F-27; Controlled Drugs and Substances Act SC 1996, c 19; Criminal Code RSC, 1985, c C-46.

36 See R Bouchard et al, 'The Pas de Deux of Pharmaceutical Regulation and Innovation: Who's Leading Whom?' (2009) 24 Berkeley Technology Law Journal 1461; P Carter, 'Federal Regulation of Pharmaceuticals in the United States and Canada' (1999) 21 Loyola of Los Angeles International and Comparative Law Journal 215; S Hwang et al, 'Universal Health Insurance and Health Care Access for Homeless Persons' (2010) 100 American Journal of Public Health 1454.

37 Based on the Canada Health Act RSC, 1985, c C-6.
} 
a) The first criterion of public administration, prescribed by Section 8, requires the following: the provincial health insurance system must be operated and administered on a non-profit basis by a public authority which is appointed or designated by the provincial government of the province; the public authority in question must be responsible to the provincial government for the said issue; the public authority in question must be subject to the audit of its accounts by a legally empowered authority.

b) The second criterion of comprehensiveness, prescribed by Section 9, requires that the provincial health insurance system must insure all insured health services which are provided by hospitals, medical practitioners or dentists, as well as the prescribed similar or additional services.

c) The third criterion of universality, prescribed by Section 10, requires that the insurance system must entitle the entire provincial population to the insured healthcare services under uniform terms and conditions.

d) The fourth criterion of portability, prescribed by Section 11, means that the provincial health insurance system must not impose a minimum period of residence in the said province, or a waiting period longer than three months before residents of the province are entitled to insured health services. Secondly, the system in question must cover the cost of insured health services provided to insured persons while temporarily absent from the province on the basis that where the insured health services are provided in Canada, costs are covered according to the tariffs of the province of treatment (unless the provinces in question make a different arrangement) and where the insured health services are provided out of Canada, costs are covered according to the tariffs of the province in which the person is insured. Thirdly, the health insurance system must provide for the payment, during any minimum period of residence, or any waiting period, imposed by the healthcare insurance system of another province, of the cost of insured healthcare services provided to persons who have ceased to be insured persons by reason of having become residents of that other province, on the same basis as though they still reside in the (first) province. Prior approval by the provincial authority may be required for elective treatments outside the province if the treatment in question was available on a similar basis within the province.

e) The fifth criterion of accessibility, prescribed by Section 12, imposes several requirements. First, the provincial health insur- 
ance system must provide for services under uniform terms and conditions and must not impede or preclude, either directly or indirectly through charges or otherwise, reasonable access to those services by insured persons. Second, the system in question must provide for payment for insured services in accordance with a tariff authorised by the law of the province. Third, the health insurance system of the province must provide for reasonable compensation for all insured healthcare treatments. Fourth, the provincial system in question must provide for the payment to hospitals, including those hospitals owned or operated by the state, in respect of the cost of insured health treatments.

It is clear that the role of the federal government in relation to provincial health insurance systems is rather different from the role of the EU in relation to Member States' social security health systems. The federal government provides for about one quarter of the financing of provincial health insurance systems. ${ }^{38}$ This financing is subject to strict conditions, based on the solidarity and universality of the healthcare provisions. In this sense, the federal government acts as an authority which oversees whether the provincial systems are based on social considerations, with medical need being the crucial criterion for healthcare provision. The money transfer and control over the social nature of the healthcare system by the central government are two important characteristics of the Canadian legal framework which differentiate it from the EU. These differences will be further elaborated in the following sections.

\section{Charter of rights and freedoms}

The previous sections analysed the Canadian legal framework dealing explicitly with access to healthcare, with a focus on the division of powers between the federal government and the provinces. Another important legal source which has, in recent years, been instrumental in changing the landscape of healthcare provision in Canada is the Canadian Charter of Rights and Freedoms. The Charter protects the rights and freedoms prescribed by its provisions subject only to those reasonable limits which are set by law as can be demonstrably justified in a democratic and free society. As stated in Oakes by the Supreme Court, ${ }^{39}$ the said limitation entails, essentially, a proportionality test, consisting of three parts. First, the measure in question must be fair and not arbitrary, designed to achieve the stated objective and connected with it. Second it must limit the right in question as little as possible. Final-

\footnotetext{
38 Marchildon (n 34) 61.

39 See $R v$ Oakes [1986] 1 SCR 103.
} 
ly, proportionality between the measure's effects and it objective must exist. ${ }^{40}$ This basic structure is generally the same as in the previously mentioned case law of the Court of Justice with an exception concerning some EU cases dealing with healthcare, as shown above, but its concrete implementation may vary between different individual cases. Healthcare is not explicitly mentioned in the Charter but some of its provisions have had an important role in terms of access to healthcare. One of these provisions is contained within Section 7 of the Charter which reads that 'Everyone has the right to life, liberty and security of the person and the right not to be deprived thereof except in accordance with the principles of fundamental justice'.

The most famous case concerning access to healthcare relating to Section 7 of the Charter is Chaoulli, decided by the Supreme Court. The case has been extensively analysed in the literature, ${ }^{41}$ so this paper will focus on its most important repercussions. The question concerned prohibition by Guebec of private insurance for healthcare services provided through public (provincial) health insurance. A similar prohibition existed in five other provinces as well ${ }^{42}$ This prohibition was challenged by George Zeliotis, who had to wait nine months for a hip operation (similar to Watts mentioned earlier), as being contrary to the Charter of Human Rights and Freedoms of Quebec $^{43}$ and the Canadian Charter of Rights and Freedoms.

The Supreme Court found the Quebec prohibition to be contrary to the Quebec Charter, while it was split three-three concerning the Canadian Charter (Justice Deschamps did not rule on the Canadian Charter). The first reason for the prohibition to be unconstitutional can be summarised by the following:

\footnotetext{
40 The Charter is a part of the Constitutional Act 1982 (UK), 1982, c 11. On the proportionality test in Canada, see, for example, D Grimm, 'Proportionality in Canadian and German Constitutional Jurisprudence' (2007) 57 University of Toronto Law Journal 383. The principle of subsidiarity is also present in the Supreme Court's jurisprudence, although not explicitly prescribed within the constitutional framework. See Reference re Assisted Human Reproduction Act [2010] 3 SCR 457.

41 See Jacques Chaoulliv Attorney General of Quebec [2005] 1 SCR. See also, for example, M Cousins, 'Health Care and Human Rights after Auton and Chaoulli' (2009) 54 McGill Law Journal 717; C Flood, K Roach and L Sossin, Access to Care, Access to Justice: The Legal Debate over Private Health Insurance in Canada (University of Toronto Press 2005); C Flood and S Lewis, 'Courting Trouble: The Supreme Court's Embrace of Private Health Insurance' (2005) 1 Healthcare Policy 26; C Flood and X Sujith, 'Health Care Rights in Canada: The Chaoulli Legacy' in A den Exter (ed), International Health Law: Solidarity and Justice in Health Care (Maklu 2008) 97.

42 Flood and Sujith (n 41) 97.

43 Charter of Rights and Freedoms, c 12.
} 
The Canada Health Act, the Health Insurance Act, and the Hospital Insurance Act do not expressly prohibit private health services. However, they limit access to private health services by removing the ability to contract for private health care insurance to cover the same services covered by public insurance. The result is a virtual monopoly for the public health scheme. The state has effectively limited access to private health care except for the very rich, who can afford private care without need of insurance. This virtual monopoly, on the evidence, results in delays in treatment that adversely affect the citizen's security of the person. Where a law adversely affects life, liberty or security of the person, it must conform to the principles of fundamental justice. This law, in our view, fails to do so. ${ }^{44}$

Furthermore:

The evidence adduced at trial establishes that many western democracies that do not impose a monopoly on the delivery of health care have successfully delivered to their citizens medical services that are superior to and more affordable than the services that are presently available in Canada. This demonstrates that a monopoly is not necessary or even related to the provision of quality public health care. ${ }^{45}$

The reasoning above is based on the conclusions that the public insurance monopoly causes waiting lists which would be reduced if freedom to obtain private insurance existed. Additionally, this kind of monopoly results in a system which is inferior to other western countries' health systems. These assumptions, with little or no empirical evidence, have been disproven in the literature. A public system providing health treatments to all insured persons on the basis of need instead of ability to pay is contrary to the very notion of a monopoly controlling prices which makes consumers worse off in the process. ${ }^{46}$ Also, countries which allow private health insurance (like the UK) have traditionally battled waiting lists, as shown when discussing EU case law on free movement of services. Further, no empirical proof that the Canadian healthcare system is generally inferior to other western countries has been provided, and these kinds of comparisons always depend on the choice of factors taken into account. ${ }^{47}$

\footnotetext{
${ }_{44}$ Chaoulli (n 41) para 106.

45 ibid, para 140.

46 Flood and Sujith (n 41) 99.

47 Concerning the proportionality of the contested measure, the Supreme Court concluded that the government has not proved that the measure minimally limits protected rights, since a wide variety of measures are available to governments, based on the examples of other countries.
} 
Putting the arguments for and against aside, the judgment is important in that it has focused on the individual's right to healthcare as a human right protected by human rights documents (in this case, primarily the provincial one). This approach neglects other aspects a social healthcare system needs to take into account. Crucially, the major beneficiaries of the majority reasoning are those persons who are able to afford private health insurance. Furthermore, possibilities to exit from a public system tend to reduce the resources available to those (who are not so well-off as to be able to afford to exit and enter private insurance) who remain. Those who suffer the most in these kinds of cases are elderly patients with chronical illnesses who either cannot enter private insurance, ${ }^{48}$ or have to pay enormous premiums to benefit from the latter. It can be seen that, in this case, the reasoning of the majority (concerning the provincial Charter) of the Supreme Court has shifted towards a more market-oriented approach with the potential of undermining the social fabric of provincial healthcare regulation based on solidarity.

The Supreme Court in Chaoulli dealt with the possibility to contract private insurance for healthcare treatments provided through public health insurance. Another issue which came to the fore is whether there exists a positive duty for the government to cover particular health treatments. The said question arose in Auton, ${ }^{49}$ regarding Section $15(1)$ of the Charter which reads that:

Every individual is equal before and under the law and has the right to the equal protection and equal benefit of the law without discrimination and, in particular, without discrimination based on race, national or ethnic origin, colour, religion, sex, age or mental or physical disability. ${ }^{50}$

In this case, a group of children diagnosed with autism and their parents claimed that the Province of British Columbia had violated their rights under Section 15(1) by refusing to fund a particular treatment for autism which they claimed was medically required.

The Supreme Court in its judgment interpreted both the Canada Health Act and the provincial legislation. According to the Court, the principle of universality prescribed by the Canada Health Act requires a provincial health insurance system to provide one hundred percent

\footnotetext{
48 See C Newdick, 'Preserving Social Citizenship in Health Care Markets: There May Be Trouble Ahead' (2008) 2 McGill Journal of Law and Health 105.

49 See Auton (Guardian ad litem of) $v$ British Columbia (Attorney General) [2003] 3 SCR 657.

50 See on this case, for example, C Bond, 'Section 15 of the Charter and the Allocation of Resources in Health Care: A Comment on Auton v British Columbia' (2005) 13 Health Law Journal 253; Cousins (n 41); M Finley, 'Limiting Section 15(1) in the Health Care Context: The Impact of Auton v British Columbia' (2005) 63 University of Toronto Faculty of Law Review 213.
} 
of qualified provincial residents with insured healthcare services under uniform terms and conditions. Insured health services are "hospital services, physician services and surgical-dental services provided to insured persons'. Hospital services are 'medically necessary' services which are provided at a hospital, while physician services are 'medically required services rendered by medical practitioners'. The principle of comprehensiveness requires a provincial health insurance system to 'insure all insured health services provided by hospitals, medical practitioners or dentists, and where the law of the province so permits, similar or additional services rendered by other health care practitioners'. Therefore, the Canada Health Act prescribes that provincial health insurance systems have to cover health services provided by hospitals and physicians, but leaves the decision on whether to cover other services to the province. The first are deemed 'core services' (services provided by physicians), and the second 'non-core services' (services not provided by physicians). The relevant provincial authority has statutory discretion to add core benefits since they are provided by medical practitioners. If the authority is satisfied that the service in question is medically required and provided by a physician, it may add this service to the list of covered services. ${ }^{51}$

It may be inferred from the judgment that the Supreme Court considers both core and non-core services to be benefits provided by law. The competent authority has the legal discretion to decide which of the core or non-core services will be covered by the provincial health insurance system as medically required services. ${ }^{52}$ The Supreme Court went on to conclude that a legislative scheme is not by itself discriminatory if it provides coverage for non-core services only for some patients and not for others. The scheme in question represented a partial health plan and, by definition, did not aim to meet all the medical needs of all patients. ${ }^{53}$

The next issue concerned was whether the provincial government excluded autistic children from coverage on the basis of disability. Here, the Court stated that the appropriate comparator for the claimants is a non-disabled person, or a person with a disability which is not a mental disability, seeking or receiving funding for a non-core treatment which is important for the present and future health of the said person, is emergent and has only recently begun to be recognised as medically required. The claimants were not denied a treatment made available to the comparator group and there was no discrimination. ${ }^{54}$

\footnotetext{
51 Auton (n 49), Appendix B.

52 Finley (n 50) 223.

53 Auton (n 49), para 43.

54 Ibid, para 8.
} 
The approach by the Supreme Court leaves the crucial autonomy to determine public healthcare coverage to the (provincial) legislature. In that sense, it refrains from making a policy choice on which treatments are to be covered from the public purse. ${ }^{55}$ The said case law shows strong restraint from engaging into judicial activism sometimes observed in the jurisprudence of the Court of Justice in some cases concerning cross-border healthcare. Importantly, there is no mention of some universal health standards which determine whether a certain treatment falls within a loose and general legislative definition of coverage. On the other hand, unlike the social health insurance systems provided by Member States of the EU, the scheme in question was partial since it included non-core services where more significant discretion of the provinces existed.

A case factually more similar to the Court of Justice's case law was Flora. ${ }^{56}$ The patient in question had contracted hepatitis $\mathrm{C}$ which resulted in a liver cancer. He was not a suitable candidate for a liver transplant in Ontario and instead underwent successful treatment to contain the growth and decrease the size of the existing tumours and received a liver transplantation procedure at a hospital in the UK. He subsequently applied for reimbursement to Ontario public authorities. The reimbursement was refused and the refusal was challenged in front of the Ontario Divisional Court and, on appeal, the Ontario Court of Appeal.

The Ontario legislation provided that a person is entitled to coverage of foreign treatment when the treatment in question is generally accepted by the medical profession in Ontario as appropriate for a patient in the same medical circumstances as the patient in question; the treatment is medically necessary; either the identical or equivalent treatment is not performed in Ontario or the identical or equivalent treatment is performed in Ontario, but it is necessary for the person to travel abroad to avoid a delay that would result in death or medically significant irreversible damage to the patient. ${ }^{57}$

The Court of Appeal rejected the appeal. In terms of the reasonableness of the decision, it concluded that it fell within the range of acceptable outcomes which are defensible on the facts and the law and that the justification was transparent, sound, and intelligible. The explicit legislative provision that the treatment in question must be generally accepted in Ontario was crucial. The question whether a treatment was accepted in medical circles elsewhere was not considered relevant. ${ }^{58}$ This

\footnotetext{
55 Bond (n 50) 271.

56 See Flora v General Manager, Ontario Health Insurance Plan, [2008] 91 O.R. (3d) 412.

57 Ibid.

58 ibid.
} 
approach is in stark contrast to the (already mentioned) approach of the Court of Justice applied in Geraets-Smits, where international standards are relevant when determining whether a treatment is covered or not. ${ }^{59}$

The other ground of appeal concerned Section 7 of the Charter. Related to this, the Court of Appeal stated that the provincial legislation's conditions for funding treatment abroad do not prohibit or impede anyone from seeking health treatment. The said rules do not limit the types of healthcare services available to Ontarians, nor do they represent governmental interference with an existing right. By not providing coverage for all treatments abroad, the provincial legislation does not deprive a person of the rights protected by Section 7 of the Charter. Finally, the Court of Appeal concluded that there is no positive right to a minimum level of healthcare guaranteed by the Charter. ${ }^{60}$

It can be stated that the case law favours personal rights over social legislation (set primarily by the provinces) in some instances. A difference between Chaoulli where that was evident and other case law is that the former was about freedom to access private health insurance, while the latter was about a positive duty of the government to cover certain health treatments. Although this distinction seems a little artificial in terms of reasoning based on improving the overall access to healthcare ${ }^{61}$ it has practically significantly limited individual rights to access healthcare. If one compares the approach of the Canadian courts to the Court of Justice of the EU, a more conservative stance can be observed. The Canadian approach generally leaves policy decisions to the provincial governments, allowing them to limit available health treatments to those provided and recognised domestically. In this way, funding and rationing decisions can be made in accordance with domestic priorities and resources.

The approach by the Court of Justice results, for example, in Member States having to cover foreign treatments not provided domestically if these treatments fall within the broad national legislative definitions of covered healthcare. These legislative definitions thereby have an unintended consequence of extending the national coverage to treatments which are normal and recognised in some other country's health system. The mentioned approach is unlike the stance of the Ontario Court of Appeal in Flora whereby only treatments recognised domestically are relevant. National legislators are thus provided with an incentive to use detailed exhaustive lists of covered treatments in order to achieve the

\footnotetext{
59 See Geraets-Smits (n 18) paras 94-98.

60 ibid.

61 Cousins (n 41) 726.
} 
goal of limiting coverage to treatments which are considered normal domestically. Their autonomy is thereby curtailed by the Court of Justice to some extent. It needs to be mentioned that this aspect of the case law has not so far resulted in systemic legislative reforms on the part of the Member States. It can be assumed that the reason for this is that cross-border healthcare is a marginal phenomenon, with only $0.05 \%$ of EU citizens obtaining healthcare abroad on the basis of the Patients' Rights Directive as a codification of the case law. ${ }^{62}$ One of the reasons for this is that people generally prefer health treatment in settings familiar to them. ${ }^{63}$ Still, the case law has affected national regulatory autonomy by creating incentives to change the way health coverage is legally defined, which may become practically more relevant depending on patient movements in the future.

\section{Lessons to be learned?}

There are similarities and differences between the ways the right to healthcare is implemented in the EU and Canada. In both systems, the main competences to organise the delivery of healthcare rest with their constituent parts (Member States/provinces). The bulk of this provision is organised via social health insurance, based on principles such as public administration, universality and accessibility. However, this is where the differences already start. It seems that the European Union acts as a regulatory state, using its powers in the area of the internal market to curb Member States' autonomy to organise their health insurance systems. This has been evident in the area of free movement of healthcare services, where the case law of the Court of Justice, codified via secondary legislation, gives the individual's right to particular health treatment priority over the needs of the system to allocate resources where they are most needed. In this way, persons who are able to pay upfront for the treatment costs and settle other related expenses, such as travel and accommodation, are privileged compared to elderly and less well-off patients who are either unable to travel longer distances or do not have enough resources to pay for the treatment and request subsequent reimbursement. Nevertheless, it should be mentioned that the described freedom has been somewhat curtailed by the more recent case law of the Court of Justice and the Patients' Rights Directive (thanks to some Member States in the Council). As mentioned in the previous

\footnotetext{
${ }_{62}$ See European Court of Auditors, 'EU Actions for Cross-border Healthcare: Significant Ambitions but Improved Management Required' (2019) 4. See also Patients' Rights Directive (n 13).

63 See S Greer, 'The Three Faces of European Union Health Policy: Policy, Markets, and Austerity' (2014) 33 Policy and Society 13, 16.
} 
sections, this development has transpired by expanding the definition of treatments for which prior authorisation is required when compared to the earliest judgments.

Still, the use of vague notions such as international medical standards entitles the mentioned privileged individuals to the best possible healthcare anywhere in the EU (which can fit into the broad legislative definition of coverage), even though a particular treatment is not recognised and, as such, practically not covered in the state of health insurance. Such an approach disrupts the balance between the various ethical and financial choices national systems have to make when determining the health services they cover. In this sense, it can be stated that the EU's role is that it facilitates the right to healthcare for one category of persons but makes the position of the other category harder by diverting resources to the first one.

All this is not currently a big practical issue due to the small extent of patient mobility, but may potentially become a more important issue depending on future trends in patient mobility, due to potential future financial crises, greater awareness of the possibilities the EU law provides to individuals, the national judiciary, and similar factors. As stated by Sindbjerg Martinsen and Vrangbaek, 'further evolution depends on the response to these developments by European citizens, private interests and national courts'. Certainly, a supportive institutional structure to expand rights stemming from EU law now exists and, unless Member State policy makers act in consort to de-institutionalise the emerging internal healthcare market, the EU influence on future health governance (its Europeanisation) will probably increase. ${ }^{64}$

Additionally, the European Union has created a strong legal framework on economic policy coordination, aiming primarily at imposing fiscal discipline upon the Member States. As stated by Scott Greer, 'To market compliance we now add fiscal compliance. ${ }^{65}$ This system has been further strengthened by the economic crisis and has resulted in reducing public healthcare expenditure, along with reforms which have, at least partially, striven for the introduction of market principles into national healthcare systems (privatisation, the increase of co-payments and the like). Importantly, forums of finance ministries rather than health experts are increasingly shaping the area with their own sets of (fiscal) priorities. ${ }^{66}$ The described setup makes it harder for individuals to exercise their right to healthcare. This is especially the case for those who

${ }_{64}$ See D Sindbjerg Martinsen and K Vrangbaek, 'The Europeanization of Health Care Governance' (2008) 86 Public Administration 169.

65 See Greer (n 63) 22.

66 ibid 22. 
are underprivileged in a way that they are not able to pay by themselves for needed healthcare services. The limited competences of the Union to concretely influence national healthcare systems, apart from the mentioned marketisation of healthcare provision, mean that the situation is not likely to change under the current EU constitutional framework.

This relationship in Canada is, at least partially, the opposite. The central government legally prescribes the basic social principles that the provincial health insurance systems must adhere to. Of course, the Canadian federal government has the legitimacy to do this because it finances part of the provincial health insurance expenses from the central budget. This redistributive role of the centre concerning healthcare is practically non-existent in the EU, which essentially tells the Member States what to do with their own money, according to the market rules on free movement and economic policy coordination. Similar attempts have been made to introduce an individual market-oriented approach in Canadian provincial health insurance systems, but the Canadian courts have proved more reluctant to go down that alley than the Court of Justice of the EU. This can be seen as part of a generally more restrained jurisprudence by the Canadian Supreme Court, in terms of allowing the central level to interfere with the areas where the provinces have the crucial role to play, than that of the Court of Justice of the EU.

It can be argued, on the basis of the analysis shown above, that the European Union could take a few lessons from Canada in terms of facilitating the right to healthcare, understood as access to healthcare services in accordance with uniform, objective criteria based on clinical need instead of the ability to pay. This state of play reflects the constitutional asymmetry of the EU. The European integration process has traditionally been dominated by the economic interests of market liberalisation and the national social policies (including healthcare) needed to be adjusted to those interests in the areas where conflicts occur. ${ }^{67}$ The same pattern can be observed in the area of healthcare. Here, free movement of well-off patients has been promoted by the Court of Justice and EU legislation to some extent, to the detriment of national policy choices prioritising resources on the basis of healthcare need instead of the ability to pay. To overcome this problem, the promotors of 'social Europe', who want to ensure the effectiveness of Member States' social systems, are faced with a choice: either to develop social programmes at the European level or harmonise national systems of social protection, including health insurance. However, the diversity of these national systems (in terms of organisation and financing) and their political salience

${ }_{67}$ See F Scharpf, 'The European Social Model: Coping with the Challenges of Diversity' (2002) 40 Journal of Common Market Studies 647. 
make it virtually impossible for the Member States to agree on common European solutions. ${ }^{68}$ As Scott Greer put it: 'adding a health treaty base might improve the health effects of EU legislation at the price of producing more EU action, while leaving no health treaty base might slow and limit EU action but at the price of ensuring it is justified by internal market law'. ${ }^{6}$

The Canadian example illustrates a possible solution to the described difficulty. Although different in many ways, EU Member States' health systems do share a set of common values of solidarity, equity, and access to good quality care and universality, as mentioned above. It can be seen that these values generally correspond to the requirements set by Canadian federal legislation for the provincial health insurance systems to obtain federal funding. Hence, it can be argued that a similar approach to the Canadian one could be applied in Europe: partial funding for the national systems provided by the EU, conditional upon respect of the social values these systems are based on. The principles of solidarity and universality, as well as the fact that government spending is predominant in ensuring access to healthcare, are crucial in this respect. Therefore, there is no rational reason why differences in the ways of funding national systems (reimbursement $\mathrm{v}$ benefits-in-kind provided free-of-charge at the point of delivery) should affect the proposal.

The mentioned proposal could be implemented if one crucial condition was met: Member States' contributions to the Union budget would have to be raised. According to Article 311 TFEU, the Council decides unanimously and after consulting the European Parliament on how to define the system of own resources of the EU. It may set new categories of own resources or abolish an existing category. Member States need to approve such a decision in accordance with their constitutional requirements. Since, under Article $6 \mathrm{TFEU}$, the EU has competence to support and supplement Member States' activities in the area of health protection, it can be claimed that financial support for national health insurance systems falls within the said area of competence.

As prescribed by Articles 311-324 TFEU, the annual budget needs to be in accordance with the multiannual financial framework which is established for a minimum period of five years. The Council, after obtaining consent from the European Parliament, adopts the multiannual financial framework regulation by way of consensus. Currently, the biggest share of expenditure is allocated for reducing economic gaps be-

68 ibid 652.

69 See Greer (n 63) 17. 
tween different regions of the EU. Rural development, agriculture, environmental protection and fisheries also represent a major share of Union spending. ${ }^{70}$

Of course, achieving consensus between EU Member States is not an easy task, especially for the countries who contribute most to the Union budget. On the other hand, resources paid into the EU budget would cover only part of health expenditure, which would make it more financially bearable. Also, a formula according to which the return would be close to proportional to the amounts paid would probably have to be developed through Member States' negotiations (with some level of solidarity with the less developed parts of the Union). ${ }^{71}$ There are several benefits to this approach. First, the EU would acquire more legitimacy to have a regulatory influence on Member States' health systems. Second, the division of competences would become clearer than now, thus contributing to legal certainty. Third, the right to healthcare for all categories of persons would be protected. If social values and the market are placed on the same constitutional footing at the EU level, the Court of Justice could more easily balance between them in individual cases, without prioritising some groups of patients over others. It is true that this approach would warrant a unanimous Council decision, but this intervention would be limited, without allowing full harmonisation of national health (insurance) systems. Of course, there are practical differences between the European Union and Canada, not limited to the fact that Canada is a single nation and in that sense is obviously more homogeneous than

\footnotetext{
70 See Europa, 'How the EU Budget Is Spent' (2018).

${ }^{71}$ It should be mentioned that there has been a proposal from the European Commission to tie funding from the European Union budget to the protection of the rule of law in individual Member States. The proposal is that Union measures against a 'problematic' Member be based on a decision by the Council following a proposal from the European Commission. See Commission, 'Proposal for a Regulation of the European Parliament and of the Council on the protection of the Union's budget in case of generalised deficiencies as regards the rule of law in the Member States' COM (2018) 324 final, art 5. There are several problems here. First, Article 322(1)(a) TFEU prescribes that regulations may be adopted, via ordinary legislative procedure, regarding the financial rules which determine particularly the procedure to be adopted for establishing and implementing the Union budget and for presenting and auditing accounts. There is no mention of the rule of law and responsibility in this primary law provision and it is very hard to infer it, since the rule of law is regulated by other Treaty provisions, namely its Article 7 . The procedure prescribed by Article 7 requires unanimity by other Member States when deciding on the existence of a persistent and serious breach by a Member State of the values the European Union is based on. Only after that would suspension of a Member State's Treaty rights be possible. Such a decision would represent an extreme course of action and the prescribed procedure and majority required should not be circumvented by using Treaty provisions not related to the principles of the rule of law. Finally, presumption in favour of a negative decision (proposed by the Commission), whereby a qualified majority is needed to decide the opposite, surely disrupts the balance of power between the Council and the Commission in favour of the Commission.
} 
the EU. This means that adopting the Canadian approach would face a lot of practical opposition within the Union setting, notwithstanding the benefits of this approach for health policy as a whole. However, in the other case, the Europeanisation of healthcare governance would be continuously torn between national and Union regulatory competence with all the problems this situation entails, as described above.

\section{CONCLUSION}

The primary responsibility to ensure the right to healthcare in complex entities like the EU and Canada rests with the level of their constituent parts. In cases where the central level actually contributes resources to enable the practical implementation of that right, it is in a position to legally protect the social character of healthcare provision and facilitate the exercise of the said right for all persons based on universal criteria. In cases where the central level acts as a market-oriented regulatory entity, healthcare systems lose their balance, and the exercise of the right to healthcare is facilitated only for privileged groups with significant economic resources. It is impossible to correct this imbalance existing in the EU without changing its constitutional framework and financial setup.

Partial funding of national health insurance systems could provide the Union with the legitimacy to take part in regulating those systems and strengthen the principles of solidarity and universality that everyone is (at least formally) so attached to. Alternatively, the current process of the Europeanisation of healthcare policy and governance would remain in a state of tension between national and EU regulatory competence with all the difficulties this involves, as illustrated in this paper. 
Table 1: EU and Canada table of comparison

\begin{tabular}{|l|l|l|}
\hline & European Union & Canada \\
\hline $\begin{array}{l}\text { Constitutional } \\
\text { provisions related to } \\
\text { healthcare }\end{array}$ & $\begin{array}{l}\text { concurrent and } \\
\text { supportive powers of } \\
\text { the EU }\end{array}$ & $\begin{array}{l}\text { exclusive powers of the } \\
\text { provinces }\end{array}$ \\
\hline $\begin{array}{l}\text { Legal basis for central- } \\
\text { level legislation }\end{array}$ & $\begin{array}{l}\text { broad powers of the EU } \\
\text { as interpreted by the } \\
\text { Court of Justice }\end{array}$ & $\begin{array}{l}\text { restrained approach } \\
\text { by the Supreme Court } \\
\text { - genuinely national } \\
\text { issues }\end{array}$ \\
\hline Financing & $\begin{array}{l}\text { Member States' } \\
\text { funding which needs } \\
\text { to adhere to economic } \\
\text { conditionality }\end{array}$ & $\begin{array}{l}\text { partial funding from } \\
\text { the federal government } \\
\text { on the condition of } \\
\text { adherence to social } \\
\text { principles }\end{array}$ \\
\hline $\begin{array}{l}\text { Right to particular } \\
\text { health treatment }\end{array}$ & $\begin{array}{l}\text { cross-border situations } \\
\text { of undue delay }\end{array}$ & $\begin{array}{l}\text { determined by } \\
\text { government policies }\end{array}$ \\
\hline $\begin{array}{l}\text { Cross-border healthcare } \\
\text { cover }\end{array}$ & international standards & domestic standards \\
\hline
\end{tabular}

\section{(c) (1) $\Theta \Theta$ \\ BY NC ND}

This work is licensed under the Creative Commons Attribution - Non-Commercial - No Derivatives 4.0 International License.

Suggested citation: T Sokol, 'The Right to Health Care in the European Union and Canada: The Role of the Centre in Complex Entities' (2019) 15 CYELP 155 